\title{
UJI AKTIVITAS JUS BUAH JAMBU BIJI BERDAGING MERAH (Psidium guajava L.) TERHADAP PENINGKATAN TROMBOSIT PADA MENCIT (Mus musculus L.) YANG DIINDUKSI KLORAMFENIKOL
}

\author{
Cindy Trie P Hosea, Abdul Wahid Jamaluddin, Yuko Mulyono Adikurniawan \\ Program Studi Kedokteran Hewan, Fakultas Kedokteran, Universitas Hasanuddin \\ Email: abdulwahidjamaluddin@unhas.ac.id;ciindyhu@gmail.com
}

\begin{abstract}
Thrombocytopenia is the most common hemostatic disorder acquired in dogs and can be a life-threatening. Guava fruit and leaves extract are believed to improve thrombocyte counts. The purpose of this study was to prove that administration of guava juice could improve thrombocyte count in mice that have thrombocytopenia after induced by chloramphenicol. We were used 24 mice as samples divided into 4 groups : KS group (given aquades for 12 days), KN group (induced by chloramphenicol for 7 days, then aquades on next 5 days), group P1 (induced by chloramphenicol for 7 days then guava juice $5 \mathrm{~g} / \mathrm{mL}$ concentration on 5 next day); and group P2 (induced by chloramphenicol for 7 days then guava juice 10 $\mathrm{g} / \mathrm{mL}$ concentration on the next 5 days). Thrombocyte count was measured three times, before treatment (day 0), after chloramphenicol induction (day 7), and after guava juice (day 12). Data of thrombocyte count was analyzed using one way Anova and Post Hoc LSD test. The results showed that the guava juice (Psidium guajava L.) concentration of $5 \mathrm{~g} / \mathrm{mL}$ and $10 \mathrm{~g} / \mathrm{mL}$ had significant effect $(p<0,05)$ to increase platelet numbers in mice after induced by chlorampenicol dose $30 \mathrm{mg} / 30 \mathrm{grBW}$.
\end{abstract}

Key words: Guava fruit, Chlorampenicol, Mice, Thrombocyte, Trombocytopenia.

\section{PENDAHULUAN}

Trombositopenia merupakan keadaan dimana jumLah trombosit berada diambang bawah dari nilai normal. Hal ini dapat terjadi akibat kegagalan produksi, peningkatan destruksi atau pemakaian, gangguan distribusi dan akibat dilusi. ${ }^{1}$ Trombositopenia tidak hanya terjadi pada manusia, namun juga pada hewan. Trombositopenia adalah kelainan hemostatik yang paling umum didapat pada anjing dan dapat menjadi ancaman yang mengancam jiwa. ${ }^{2}$ Trombositopenia berat pada anjing sebagian besar dimediasi oleh kekebalan, terutama terjadi pada anjing betina dewasa jenis Cocker spaniels, Old English sheepdogs, German shepherd, dan Poodles. Namun, jumLah trombosit yang rendah juga umumnya terkait dengan penyakit inflamasi, infeksius atau neoplastik. Infestasi caplak dan kanker adalah 
Uji aktivitas jus buah jambu biji berdaging merah (Psidium guajava L.) terhadap peningkatan trombosit pada mencit (Mus musculus L.) yang diinduksi kloramfenikol

penyebab utama yang dilaporkan pada hewan dengan kejadian trombositopenia. JumLah trombosit yang rendah diyakini umum terkait dengan penyakit inflamasi, infeksius atau neoplastic. ${ }^{3,4}$

Sampai saat ini tindakan pengobatan yang dilakukan hanya berdasarkan gejala yang timbul atau dengan terapi pendukung. Beberapa bahan herbal telah terbukti dapat meningkatkan total trombosit darah, salah satunya adalah buah jambu biji. ${ }^{5}$ Aktivitas kuersetin dalam jambu biji dapat menurunkan kerusakan selaput sel saraf yang disebabkan oleh virus ${ }^{6}$. Selain itu jambu biji juga mempunyai aktivitas aktif yang lain seperti antibakteri pada bakteri zoonosis Proteus mirabilis. $^{7}$

Berdasarkan uraian di atas maka dianggap perlu untuk dilakukan penelitian lebih lanjut mengenai " Uji aktivitas jus buah jambu biji berdaging merah (Psidium guajava L.) terhadap peningkatan trombosit pada mencit (Mus musculus L.) yang diinduksi kloramfenikol".

\section{METODE KERJA}

\section{Alat dan Bahan}

Alat yang digunakan sonde (kanula), neraca, kandang hewan, sekam kandang, kawat, wadah makanan minuman hewan coba, timbangan analitik, gelas ukur $100 \mathrm{~mL}$, kain saring, sendok, kompor, kaca objek, penutup kaca, mikroskop, rak slide, spoit, masker, dan handskun. Sedangkan bahan yang digunakan buah jambu biji merah, obat kloramfenikol, pakan AD2, air, akuades, $\mathrm{Na} \mathrm{CMC} 1 \%$, metanol, cat warna giemsa, dan sampel darah mencit.

\section{Pembuatan jus jambu biji}

Bahan penelitian yang digunakan adalah buah jambu biji merah yang diperoleh dari daerah Makassar. Daging buah jambu biji dicampur dengan akuades dan dibuat masing-masing dosis $5 \mathrm{~g} / \mathrm{mL}$ dan 10 $\mathrm{g} / \mathrm{mL}$. Bahan kemudian dihaluskan menggunakan blender dan disaring menggunakan kain untuk menghasilkan jus yang diinginkan.

\section{Perlakuan terhadap hewan uji}

Sebelum penelitian dimulai, mencit diadaptasikan terlebih dahulu sesuai dengan standar manajemen pemeliharaan hewan di Laboratorium Biofarmasi Fakultas Farmasi Universitas Hasanuddin. Hal ini dilakukan dengan tujuan mengurangi tingkat stres hewan coba sebelum diberi perlakuan. Keadaan kandang perlu dijaga agar kondisi hewan coba tetap sehat. 
Uji aktivitas jus buah jambu biji berdaging merah (Psidium guajava L.) terhadap peningkatan trombosit pada mencit (Mus musculus L.) yang diinduksi kloramfenikol

Untuk menginduksi keadaan trombositopenia digunakan kloramfenikol dengan dosis uji berdasarkan penelitian yang dilakukan Setiawan ${ }^{8}$, yang secara nyata telah dapat menurunkan nilai trombosit pada tikus. Dosis ini kemudian dikonversi ke dosis mencit didapat $30 \mathrm{mg} / 30 \mathrm{~g}$ ekor mencit. Didapat dari hasil orientasi bahwa dosis tersebut selama 7 hari secara peroral sudah mampu menurunkan jumLah trombosit darah pada mencit.

Mencit jantan sebanyak 24 ekor yang telah diadaptasikan selama satu minggu dibagi menjadi 4 kelompok. Subjek dikelompokkan menjadi empat kelompok secara random, dan masingmasing kelompok terdiri dari 6 ekor mencit jantan. Adapun pengelompokan subjek adalah sebagai berikut:

a. Kontrol Sehat (KS) : sampel diberikan pakan standar dan akuades setiap hari selama 12 hari berturut-turut.

b. Kontrol Negatif (KN) : sampel diberikan kloramfenikol dosis $30 \mathrm{mg} / 30 \mathrm{gBB}$ peroral selama 7 hari dan akuades selama 5 hari berikutnya serta pakan standar.

c. Perlakuan 1 : sampel diberikan kloramfenikol dosis $30 \mathrm{mg} / 30 \mathrm{~g}$ BB selama 7 hari dan jus jambu biji dosis $5 \mathrm{~g} / \mathrm{mL}$ selama 5 hari berikutnya serta pakan standar.

d. Perlakuan 2 : sampel diberikan kloramfenikol dosis $30 \mathrm{mg} / 30 \mathrm{gBB}$ selama 7 hari dan jus jambu biji dosis $10 \mathrm{~g} / \mathrm{mL}$ selama 5 hari berikutnya serta pakan standar.

Pemberian perlakuan dilakukan selama 12 hari. Setiap sebelum pemberian kloramfenikol dan jus jambu biji peroral, mencit dipuasakan dahulu \pm 3 jam untuk mengosongkan lambung.

\section{Pemeriksaan darah}

Pemeriksaan trombosit dilakukan pada hari ke 0 , ke 7 , dan hari ke 12. Perhitungan jumlah trombosit dengan menggunakan apusan darah tepi. Darah diambil pada ekor, lalu dibuat apusan pada slide.

Perkiraan jumlah trombosit / $\mu \mathrm{L}$ $=$ jumlah rata-rata di 10 bidang $\mathrm{x}$ 20.000. Mencit dikatakan mengalami trombositopenia apabila jumlah trombosit dibawah dari 285 - 890 $\mathrm{x} 10^{3} / \mathrm{mm}^{3}{ }^{9}$ Pengamatan dan pencatatan dilakukan terhadap jumlah trombosit selama 12 hari perlakuan.

\section{HASIL PENELITIAN}

\section{Hasil perhitungan trombosit darah}

Perhitungan jumlah trombosit darah hewan uji dilakukan sebanyak 3 kali dengan menggunakan metode apusan darah tepi. Adapun hasil 
Uji aktivitas jus buah jambu biji berdaging merah (Psidium guajava L.) terhadap peningkatan trombosit pada mencit (Mus musculus L.) yang diinduksi kloramfenikol

perhitungan nilai rata - rata jumlah trombosit dari masing - masing kelompok hewan uji ditunjukkan pada Tabel 1.

Tabel 1. Rata-rata jumlah trombosit hewan uji

\begin{tabular}{|c|c|c|c|c|}
\hline Kelompok & $\mathbf{N}$ & $\begin{array}{c}\text { Hari ke 0 } \\
\left(10^{3} / \mathrm{mm}^{3}\right) \pm s t d\end{array}$ & $\begin{array}{c}\text { Hari ke } 7 \\
\left(10^{3} / \mathrm{mm}^{31}\right) \pm s t d\end{array}$ & $\begin{array}{c}\text { Hari ke } 12 \\
\left(10^{3} / \mathrm{mm}^{3}\right) \pm s t d\end{array}$ \\
\hline KS & 6 & $402,33 \pm 40,10$ & $406.5 \pm 24,09$ & $414.0 \pm 34,08$ \\
\hline KN & 6 & $341,33 \pm 72,57$ & $179,66 \pm 27,02$ & $279,33 \pm 17,60$ \\
\hline P1 & 6 & $367.0 \pm 76,98$ & $183.0 \pm 38,02$ & $475,33 \pm 46,91$ \\
\hline $\mathbf{P 2}$ & 6 & $373,66 \pm 62,16$ & $171,33 \pm 39,65$ & $551,66 \pm 25,12$ \\
\hline
\end{tabular}

* Keterangan: KS (pakan standar dan akuades), KN (kloramfenikol 30mg/30gBB dan akuades), P1 (kloramfenikol 30 mg/30gBB dan jus jambu biji $5 \mathrm{~g} / \mathrm{mL}$ ), P2 (kloramfenikol $30 \mathrm{mg} / 30 \mathrm{gBB}$ dan jus jambu biji 10 $\mathrm{g} / \mathrm{mL})$.

\section{Persentase peningkatan trombosit darah mencit}

Tabel 2. Persentase (\%) penurunan dan peningkatan jumlah trombosit darah mencit.

\begin{tabular}{cccc}
\hline \multirow{2}{*}{ Kelompok } & \multicolumn{3}{c}{ Persentase terhadap waktu perlakuan } \\
\cline { 2 - 4 } & Hari ke 0 (\%) & Hari ke 7 (\%) & Hari ke 12 (\%) \\
\hline KS & 0,00 & $1,03(\uparrow)$ & $1,81(\uparrow)$ \\
KN & 0,00 & $47,36(\downarrow)$ & $35,68(\uparrow)$ \\
P1 & 0,00 & $50,13(\downarrow)$ & $165,57(\uparrow)$ \\
P2 & 0,00 & $54,14(\downarrow)$ & $221,99(\uparrow)$ \\
\hline
\end{tabular}

${ }^{\star}$ Keterangan : KS (Kontrol Sehat), KN (Kontrol Negatif), P1 (Perlakuan 1), P2 (Perlakuan 2), ( $\uparrow$ mengalami peningkatan, $(\downarrow)$ mengalami penurunan.

\section{Hasil analisis perhitungan jumlah trombosit darah mencit}

Tabel 3. Hasil analisis statistik ANOVA

\begin{tabular}{cc}
\hline Perlakuan & Signifikansi \\
\hline Trombosit 0 & 0,456 \\
Trombosit 1 & 0,000 \\
Trombosit 2 & 0,000 \\
\hline
\end{tabular}

Tabel 4. Hasil uji LSD terhadap rata-rata jumlah trombosit

\begin{tabular}{cccc}
\hline Kelompok & $\begin{array}{c}\text { Hari ke 0 } \\
\left(10^{3} / \mathbf{m m}^{3}\right) \pm \mathbf{s t d}\end{array}$ & $\begin{array}{c}\text { Hari ke 7 } \\
\left(\mathbf{1 0} / \mathbf{m m}^{3}\right) \pm \mathbf{s t d}\end{array}$ & $\begin{array}{c}\text { Hari ke 12 } \\
\left(\mathbf{1 0} \mathbf{m}^{3} \mathbf{m m}^{3}\right) \mathbf{s t d}\end{array}$ \\
\hline KS & $402,33 \pm 40,10^{\mathrm{a}}$ & $406.50 \pm 24,09^{\mathrm{a}}$ & $414.00 \pm 34,08^{\mathrm{a}}$ \\
KN & $341,33 \pm 72,57^{\mathrm{a}}$ & $179,66 \pm 27,02^{\mathrm{b}}$ & $279,33 \pm 17,60^{\mathrm{b}}$ \\
P1 & $367.00 \pm 76,98^{\mathrm{a}}$ & $183.00 \pm 38,02^{\mathrm{b}}$ & $475,33 \pm 46,91^{\mathrm{c}}$ \\
P2 & $373,66 \pm 62,16^{\mathrm{a}}$ & $171,33 \pm 39,65^{\mathrm{b}}$ & $551,66 \pm 25,12^{\mathrm{d}}$ \\
\hline
\end{tabular}

${ }^{*}$ Keterangan : a, b, c, d, yang berbeda menandakan perbedaan signifikansi $(p<0,05)$ antar kelompok KS, KN, $\mathrm{P} 1$, dan P2.

\section{PEMBAHASAN}

Perhitungan trombosit awal (hari ke 0) pada tabel 1 menunjukkan nilai rata - rata jumlah trombosit pada masing - masing kelompok sebelum pemberian perlakuan berada pada 
Uji aktivitas jus buah jambu biji berdaging merah (Psidium guajava L.) terhadap peningkatan trombosit pada mencit (Mus musculus L.) yang diinduksi kloramfenikol

kisaran normal 10 yang hasilnya hampir sebanding dari keempat kelompok. Adanya perbedaan nilai rata - rata jumlah trombosit disebabkan oleh variasi biologis, dimana jumlah trombosit dipengaruhi oleh berbagai faktor seperti usia, jenis kelamin, musim, dan tempat hidup. Namun faktor ini dihilangkan karena semua hewan uji yang digunakan dalam penelitian ini memiliki faktor yang relatif sama seperti berat badan, kondisi yang sehat, dan diberi pakan yang sama. Rata - rata trombosit semua mencit pada hari ke 0 sebelum pemberian perlakuan yaitu $371,08 \pm$ $64,14 \times 10^{3} / \mathrm{mm}^{3}$.

Data pada hari ke 7 merupakan hasil perhitungan trombosit pada hari ke 7 setelah pemberian kloramfenikol. Kloramfenikol diberikan pada semua kelompok (KN, P1, dan P2) kecuali kelompok kontrol sehat (KS) untuk menurunkan kadar trombosit darah. Berdasarkan tabel 5, hasil perhitungan trombosit pada hari ke 7 menunjukkan penurunan jumlah trombosit pada semua kelompok perlakuan pemberian kloramfenikol. Selanjutnya kelompok P1 dan P2 diberikan jus buah jambu biji dengan konsentrasi masing-masing $5 \mathrm{~g} / \mathrm{ml}$ dan $10 \mathrm{~g} / \mathrm{ml}$ selama 5 hari untuk meningkatkan kembali kadar trombosit lalu dilakukan perhitungan pada hari ke 12. Diagram peningkatan trombosit pada masing - masing kelompok selama perlakuan dapat dilihat pada gambar di bawah ini.

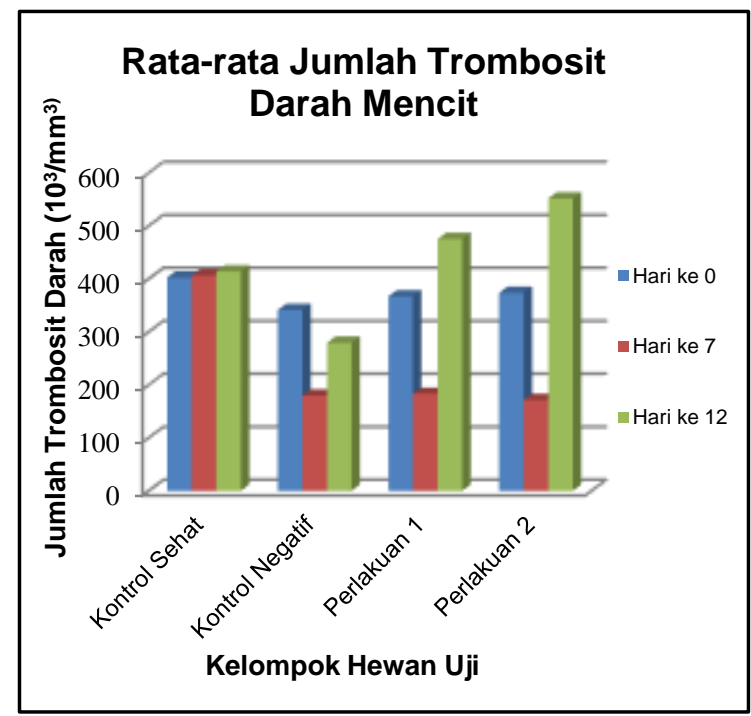

Gambar 1. Diagram rata - rata jumlah trombosit darah mencit.

Berdasarkan gambar 1 dapat dilihat bahwa terdapat perbedaan jumlah trombosit sebelum perlakuan (hari ke 0), setelah pemberian kloramfenikol (hari ke 7), dan setelah pemberian jus buah jambu biji (hari ke 12), pada masing - masing kelompok.

Tabel 2 menunjukkan persentase jumlah trombosit kelompok KS dari hari 0 ke hari ke 7 mengalami peningkatan sebesar $1 \%$ kemudian dari hari ke 7 ke hari 12 mengalami peningkatan sebesar $1,81 \%$. Whittaker et $\mathrm{al}^{11}$ melaporkan peningkatan volume platelet rata-rata sebagai respon terhadap latihan meskipun hanya sementara. Peningkatan ini 
Uji aktivitas jus buah jambu biji berdaging merah (Psidium guajava L.) terhadap peningkatan trombosit pada mencit (Mus musculus L.) yang diinduksi kloramfenikol

disebabkan oleh hemokonsentrasi dan pelepasan trombosit dari hati, paruparu, dan yang terpenting. Kelompok $\mathrm{KN}, \mathrm{P} 1$, dan $\mathrm{P} 2$, mengalami penurunan yang berarti sebesar 47,36 ; 50,$13 ; 54,14 \%$ dari hari 0 ke hari ke 7 . Sedangkan dari 7 ke hari 12 mengalami peningkatan sebesar $35,68 \%$; $\quad 165,57 \% ; \quad 221,99 \%$. Peningkatan tertinggi terjadi pada kelompok perlakuan 2 (P2) dengan konsentrasi jus buah jambu biji 10\% telah mampu meningkatkan total trombosit darah kembali ke nilai normal dengan persentasi kenaikan yaitu 221,99\%. Ini membuktikan bahwa kandungan buah jambu biji dapat berpengaruh terhadap peningkatan trombosit mencit.

Hasil analisis statistik One way ANOVA menunjukkan bahwa perhitungan trombosit 0 tidak memperlihatkan perbedaan yang signifikan ( $p>0,05$ ) karena belum adanya perlakuan. Trombosit 1 memperlihatkan bahwa kloramfenikol memberikan pengaruh yang signifikan $(p<0,05)$ berupa penurunan trombosit. Sedangkan jambu biji memberikan pengaruh yang signifikan $(p<0,05)$ terhadap peningkatan trombosit pada kelompok perlakuan, sehingga pemberian jus buah jambu biji berpengaruh secara nyata $(p=0,00$
$<0,05)$ terhadap peningkatan trombosit setelah diinduksi kloramfenikol.

Pengujian lanjutan untuk menghitung nilai kelompok berbeda dan memiliki perbandingan yang signifikan yaitu dengan uji Post $\mathrm{Hoc}$ Test metode Least Significant Difference (LSD) pada setiap waktu pemeriksaan darah. Intrepretasi hasil uji LSD terhadap kelompok dengan nilai signifikansi $p<0,05$ menunjukkan ada perbedaan yang signifikan.

Jumlah trombosit menunjukkan total trombosit yang terdapat di dalam darah. Tabel 4 menunjukkan nilai rata - rata jumlah trombosit hewan uji selama penelitian, dari tabel tersebut terlihat bahwa nilai trombosit pada pemeriksaan awal (hari ke 0) tidak menunjukkan perbedaan yang signifikan berdasarkan analisis melalui uji LSD. Uji LSD untuk pemeriksaan ke 2 (hari ke 7) setelah pemberian kloramfenikol untuk kelompok KN, P1, dan P2, menunjukkan adanya perbedaan yang signifikan antara kelompok $\mathrm{KS}$ dengan $\mathrm{KN}, \mathrm{P} 1$, dan $\mathrm{P} 2$ $(p<0,05)$. Sementara ketiga perlakuan yang diberikan kloramfenikol tidak menunjukkan adanya perbedaan yang signifikan $(p=0,862 ; 0,665 ; 0,546>$ $0,05)$. Hal ini berarti bahwa pemberian kloramfenikol dapat menyebabkan penurunan Jumlah trombosit setelah 
Uji aktivitas jus buah jambu biji berdaging merah (Psidium guajava L.) terhadap peningkatan trombosit pada mencit (Mus musculus L.) yang diinduksi kloramfenikol

diberikan selama 7 hari. Kehilangan total trombosit darah merupakan akibat dari penggunaan kloramfenikol dosis toksik yang dapat menyebabkan kerusakan sumsum tulang yang berhubungan dengan gangguan pada sel-sel hemopoietik. Hal ini menimbulkan depresi sumsum tulang belakang yang menyebabkan diskrasia darah dimana sumsum tulang belakang tidak mampu memproduksi butir darah merah dan pembuatan selsel darah merah terganggu sehingga terjadi anemia aplastik atau hipoplastik, trombositopenia dan granulositopenia $^{12}$. Penelitian yang dilakukan oleh Shukla dan singh ${ }^{13}$ melaporkan bahwa kloramfenikol menyebabkan hemotoksisitas yang ditandai dengan penurunan pada sel darah merah, sel darah putih, dan trombosit. Menurut Turton, et $\mathrm{al}^{14}$ efek penghambatan kloramfenikol bersifat sementara, sehingga trombositopenia yang terjadi biasanya ringan dan produksi trombosit akan kembali ke kondisi normal.

Pemeriksaan ke 3 (hari ke 12), hasil uji LSD menunjukkan bahwa keempat perlakuan memberikan perbedaan yang sangat signifikan. Kelompok kontrol sehat (KS) dan kelompok kontrol negatif (KN) menunjukkan nilai signifikan yang bermakna $(p=0,000)$. Hal ini karena kelompok kontrol negatif yang diberikan kloramfenikol telah mengalami peningkatan trombosit namun belum mencapai nilai normal seperti kelompok pemberian jus buah jambu biji. Nilai signifikan kelompok KS terhadap $P 1$ yaitu $p=0,044$, sementara untuk kelompok KS terhadap $P 2$ yaitu $p=0,01$.

Hasil penelitian menunjukkan bahwa pada kelompok P1 dan P2 sama - sama mengalami peningkatan jumlah trombosit di hari ke 12 setelah pemberian jus buah jambu biji, yang mana sebelumnya telah diberikan kloramfenikol untuk menurunkan kadar trombositnya. Kemungkinan peningkatan ini disebabkan pemberian jus buah jambu biji. Buah jambu biji yang digunakan diduga mengandung berbagai unsur vitamin, flavonoid dan senyawa polifenol. Berdasarkan penelitian yang dilakukan oleh Joseph et $\mathrm{al}^{15}$, penelitian lain menunjukkan bahwa kuersetin pada jambu biji mampu meningkatkan jumlah megakariosit dan trombosit. ${ }^{16}$

Kuersetin dapat meningkatkan kadar trombosit darah dengan meningkatkan ekspresi mRNA SCF (stem cell factor) di sel stroma sumsum tulang. Selanjutnya, SCF merangsang produksi platelet dengan 
Uji aktivitas jus buah jambu biji berdaging merah (Psidium guajava L.) terhadap peningkatan trombosit pada mencit (Mus musculus L.) yang diinduksi kloramfenikol

meningkatkan sekresi IL-6 sel mast yang menginduksi hati untuk mensekresikan thrombopoietin. Selain hematopoiesis, SCF juga terlibat dalam proliferasi sel hati. ${ }^{17}$

Berdasarkan data diatas dapat disimpulkan bahwa kelompok perlakuan 1 dan perlakuan 2 memiliki perbedaan terhadap kelompok kontrol sehat, namun tidak lebih signifikan dibanding kontrol negatif terhadap kontrol sehat. Pemberian kloramfenikol pada setiap kelompok perlakuan menunjukkan penurunan trombosit dibandingkan dengan kelompok kontrol negatif yang tidak diberikan perlakuan. Adapun kelompok yang diberikan kloramfenikol yaitu kelompok $\mathrm{KN}$, P1, dan P2, yang menunjukkan penurunan jumlah trombosit. Sedangkan jumlah trombosit setelah pemberian jus jambu biji pada kelompok perlakuan yaitu $\mathrm{P} 1$ dan $\mathrm{P} 2$ mengalami peningkatan dari nilai sebelumnya.

\section{KESIMPULAN}

Berdasarkan hasil penelitian yang dilakukan, dapat disimpulkan bahwa pemberian jus buah jambu biji berdaging merah (Psidium guajava L.) konsentrasi $5 \mathrm{~g} / \mathrm{mL}$ dan $10 \mathrm{~g} / \mathrm{mL}$ memiliki aktivitas dalam meningkatkan trombosit darah mencit dan pemberian jus buah jambu biji konsentrasi 10 $\mathrm{g} / \mathrm{mL}$ selama 5 hari pada mencit (Mus musculus L.) menunjukkan peningkatan trombosit paling tinggi diantara perlakuan lainnya.

\section{DAFTAR PUSTAKA}

1. Chartier, Marie. Canine Primary (Idiopathic) Immune-Mediated Thrombocytopenia. Ivg Metrowest. 2015. Available On Cliniciansbrief. Com.

2. Grindem $\mathrm{CB}$, EB Breitschwerdt, WT Corbett and HE Jans. Epidemiologic Survey of Thrombocytopenia in Dogs: A Report on 987 Cases. Vet Clin Pathol. 1991:20: 38-43.

3. Bommer NX, DJ Shaw, EM Milne, and $A E$ Ridyard. Platelet Distribution Width and Mean Platelet Volume in the Interpretation of Thrombocytopenia in Dogs. J Small Anim Pract. 2008; 49, 518-524.

4. Botsch V, H Kuchenhoff, K Hartmann, and $J$ Hirschberger. Retrospective Study of 871 Dogs with Thrombocytopenia. Vet Rec.2009;164:647-651.

5. Kullu, AR, W Tabassum, and $P$ Sinha. Effects of Psidium Guajava Aqueous Extracts on Haematological Profile and Serum Lipid Variables of Albino Rats. The Bioscan. 2013;8(2):743-746.

6. Heo $\mathrm{H}$, and $\mathrm{C}$ Lee. Intracellular metabolism bioactivity of quercetin. J Agric Food Chem.2004;52:75-9.

7. Jamaluddin AW, Muslimin LW, Djide MN. Ekstrak Daun Jambu Biji (Psidium guajava L) sebagai inhibitor pertumbuhan bakteri zoonosis proteus mirabilis yang 
Uji aktivitas jus buah jambu biji berdaging merah (Psidium guajava L.) terhadap peningkatan trombosit pada mencit (Mus musculus L.) yang diinduksi kloramfenikol

diisolasi dari daging ayam broiler. Jurnal As-Syifaa.2018;10(01):3036.

8. Setiawan $\mathrm{CH}$. Pengaruh Pemberian Angkak Terhadap Kenaikan Jumlah Trombosit Tikus Jantan. Jurnal Farmasi Sains dan Komunitas.2015;12(1):15-21.

9. Santos EW, DC Oliveira, A Hastreiter, GB Silva, JS Beltran, M Tsujita et al. Hematological and Biochemical Reference Values for C57BL/6, Swiss Webster And BALB/C Mice Braz J Vet Res Anim Sci.2015;53(2):138-145.

10. Moore DM. Hematology of the mouse (Mus musculus), in Schalm's veterinary hematology, 5th ed., edited by B.F. Feldman, J.G. Zinkl \& N.C. Jain. New York: Lippincott Williams \& Wilkins, 2000.

11. Whittaker JP, MD Linden, and VG Coffey. Effect of aerobic interval training and caffeine on blood platelet function. Medicine \& Science in Sports \& Exercise. 2013.45(2):342-350.

12. Winarno FG. Masalah Khloramfenikol pada produksi udang di Indonesia. Jakarta: Departemen Perikanan dan Kelautan, 2002.
13. Shukla P and RK Singh. Effect of oral administration of chloramphenicol on hematological profile of male charles foster rats. Global journal of medical research pharma, drug discovery, toxicology and medicine. 2013;13.

14. Turton JA, R Fagg, WR Sones, TC Williams, CM Andrews. Characterization of the Myelotoxicity of Chloramphenicol Succinate in the B6C3F1 Mouse. International Journal of Experimental Pathology.2006;82.

15. Joseph L, M George, G Singh, $P$ Mathews. Phytochemical investigation on various parts of Psidium guajava. Annals of Plant Sciences. 2016;5(2):1265-1268.

16. Soegijanto S, MS Azhali, AR Tumbelaka, Anggraini, R Rufiati, DD Sary. Uji Klinik Multisenter Sirup Ekstrak Daun Jambu Biji pada Penderita Demam Berdarah Dengue. Medicinus.2007;23(1).

17. Atik N, S Tarawifa, E Afriyanti, AR Rahmadi, D Hilmanto. Psidium Guajava L. Extract Increases Platelet Count Through Enhancement of Stem Cell Factor Expression in Thrombocytopenic Mice Model. International Journal of Pharmacy and Pharmaceutical Sciences.2017;10 (1). 